\title{
Cebrin Semantiği: Hârizmî Cebrinin Felsefi Açıdan Değerlendirmesi
}

\author{
Tuğba Yavuz ${ }^{1 *}$ \\ ${ }^{1}$ Yazar Üniversitesi, Yazar Fakültesi, Yazar Bölümü, Ankara, Türkiye \\ ORCID: Yazar Kasolu (0000-0001-8405-7845)
}

\begin{abstract}
Özet
Muhammed b. Mûsa el-Hârizmî'nin 843 yılında kaleme aldığı el-Kitâbu'l Muhtasar fi Hisâbi'l Cebr ve'l Mukâbele isimli kitabı kısa bir süre önce ilk kez Türkçeye çevrildi. Bu çalışmada, söz konusu çeviriden hareketle, Hârizmî cebrinin metafizik ve semantik yorumlarını içeren felsefi bir değerlendirmesi sunulmuştur. Hârizmî, cebirsel denklemlerin çözümünde geometrik modelleme yaparak anlamsal bir zemine bağlı kalmış ve irrasyonel sayılara denklem çözümlerinde yer verirken, negatif kökleri araştırmayı bilinçli bir şekilde tercih etmemiştir. Hârizmînnin kendi cebir sistemini inşa ederken benimsediği bu yaklaşım ve kullandığı yöntem, matematiği nasıl bir metafizik ve semantik zeminde yaptığına dair ipuçları verir. Bu ipuçları, yalnızca genel itibariyle cebir ya da Hârizmî cebri için değil, mümkün ve imkansız dünyalar semantiği ya da nesne kuramına ilişkin farklı yaklaşımların önemli bir yer tuttuğu çağdaş felsefe ve mantık tartışmaları açısından da son derece önemlidir. Günümüz tartışmalarına ışık tutabilmesi ve farklı yorumlara kapı aralamak amacıyla, Hârizmî ve cebrinin genel özellikleri, matematik ve metafizik ilişkisi ve Hârizmî cebrinin metafizik ve semantik temellerinden yola çıkarak güncel nesne tartışmaları bağlamındaki değerlendirmesi bu çalışmanın ana teması olacaktır.
\end{abstract}

Anahtar Kelimeler: Hârizmî, cebir, modal mantık, semantik, metafizik

\section{The Semantics of Algebra: Philosophical Considerations of Al-Khwarizmi's Algebra}

\begin{abstract}
The book el-Kitâbu'l Muhtasar fi Hisâbi'l Cebr ve'l Mukâbele written by Muhammed b. Mûsa al-Khwarizmi in 843 recently translated into Turkish for the first time. This paper, based on the translation, presents its semantic and metaphysical interpretations from a philosophical point of view. Al-Khwarizmi, by using geometric models in the solution of algebraic equations, adhered to a semantic basis and while including irrational numbers in the solutions, consciously preferred not to find negative roots. This approach and the method that al-Khwarizmi adopted while constructing his algebraic system give clues about what kind of metaphysical and semantic ground he took basis in doing mathematics. These clues are very important not only for algebra in general and al-Khwarizmi's algebra but also for contemporary discussions in philosophy and logic in which the various approaches to possible and impossible world semantics and object theories hold and important place. In order to shed light on today's debates and open the door to different interpretations, the general features of al-Khwarizmi and his algebra, the relationship between mathematics and metaphysics, and the evaluation of the metaphysical and semantic foundations of al-Khwarizmi's algebra in the context of contemporary discussions on object theories will be the main theme of this study.
\end{abstract}

Keywords: al-Khwarizmi, algebra, modal logic, semantic, metaphysics

\section{Giriș}

Kaleme alınışından tam on iki asır sonra bugün henüz günümüz bilim literatürüne kazandırılabilen Hârizmî'nin el-Kitâbu'l Muhtasar fi Hisâbi'l Cebr ve'l Mukâbele (kısaca Cebr diye anılacaktır) adlı kitabı, yazıldığı dönemde olduğu gibi bugün hala matematik alanında önemli bir kaynaktır. Bunun yanında, çok önemli felsefi çıkarımlara izin veren bir içeriğe de sahiptir. Aslında her matematik kitabı, aynı zamanda bir felsefe kita-

*Yazıșma Adresi / Address for Correspondence:

T. Yavuz, Email: tughba.yavuz@gmail.com

Geliş Tarihi / Received Date: 04.10.2021

Kabul Tarihi / Accepted Date: 01.11.2021

Doi: $10.32329 /$ uad. 1004370 bıdır. Çünkü matematiğin sınırları, felsefenin en temel, en önemli konusu olan varlığın sınırlarına dair ihtiyaç duyulan ipuçlarını verir. Bu perspektiften, Hârizmî’nin Cebr'i de bir felsefe kitabı olarak okunabilir. Esasında tarihsel sürece baktığımızda, yakın bir geçmişe kadar bilimle uğraşan kimseler aynı zamanda felsefeyle, hatta edebiyatla da ilgilenirlerdi. Daha doğrusu, felsefe, bugün farklı disiplinler olarak karşımıza çıkan bilimleri de içeren bir anlamda kullanılmaktaydı. Hârizmî her ne kadar farklı bilim dallarıyla ilgilenmiş olsa da, felsefeye özel bir ilgisi ya da felsefi meseleler üzerine kaleme aldığı bilinen bir metni yoktur. Ancak onun Cebr'inin felsefi bir okuması yapıldığında, metafizik ve semantik çıkarımlar yapmak oldukça mümkündür. Dahası, her ne kadar kendisi doğrudan cebrin metafizik ve semantiğiyle ilgilendiğine dair bir söylemde bulunmamış olsa da, metafiziksel 
bir temel üzerinde ve semantik kaygılarla cebrini inşa ettiği çok açıktır.

Çağdaş felsefi tartışmaların odağında, Aydınlanma ile başlayan metafiziği felsefeden dışlama sürecinin aksine, 20. yüzyılda geliştirilen mantık sistemleri (özellikle modal mantık) sayesinde klasik anlayışa nispetle sınırları bir hayli genişleyen metafizik ve semantik yer almaktadır. Klasik metafiziğin sınırları uzam-zamansal olanla mütekabiliyet içerisinde düşünülen nesne anlayıșının dıșına çıkamazken, bugün metafiziğin sınırları bu dünyada bilfiil varolmayan fakat mümkün ya da imkansız bir dünyada varlığı düşünülebilen mümkün ve imkansız nesneleri içerecek ölçüde genişlemiştir. Bunu mümkün kılan ise klasik Aristoteles mantığının modal mantık ve modal semantikle ikame edilmesidir. Hârizmî Cebr'ini konumuz açısından önemli kılan, temelinde yer aldığını düşündüğümüz ve ona dayanak olan metafizik ve semantik yaklaşımdır. Zira bu yaklaşım, (henüz) bireyleştirilememiş nesneden matematiksel bir çerçeve içerisinde bahsetmeyi, ona nesne olarak yer vermeyi, bir diğer ifadeyle varolmayan nesneyi nesne kuramında içermeyi mümkün kılmaktadır.

Bu çalışmada, Cebr'in temelinde yer aldığını düşündügümüz söz konusu bu metafizik ve semantik yaklaşım üzerinde durulacaktır. Hârizmî'nin hayatı ve Cebr'e ilişkin kısa bir girişin ardından metafizik ve semantiğin öncelikle matematikle, sonra da Hârizmî cebriyle nasıl bağlantılı olduğunu anlayabilmek adına, ilk olarak, felsefe tarihi boyunca matematiğin yeri ve matematiksel düşüncenin önemine yer verilecektir. Ardından, Hârizmî Cebr'inin modern nesne kuramı bağlamında metafiziksel değerlendirmesi yapılacak ve sonrasında ise geometrik modelleme ile nasıl bir semantik yoruma izin verdiğine değinilecektir.

\section{CEBR'E GENEL BİR BAKIŞ}

Asıl adı Ebû Ca'fer Muhammed b. Mûsâ el-Hârizmî olan yazar, kesin olmamakla birlikte 780 dolaylarında bugün Özbekistan sınırları içinde kalan Harizm bölgesinde dünyaya gelmiştir. Bu bölgede doğmuş olması, ömrünün büyük çoğunluğunu Bağdat'ta geçirmiş olması ve Sünni itikat üzere yaşamış olması Türk olduğu yönündeki düşünceleri güçlendirse de aslen İranlı mı yoksa Türk mü olduğu hususunda kesin bir delil yoktur. (Ekinci, 2021, s. 104; Fazlığlu, 1997, s. 224)

Matematiğin yanında coğrafya ve astronomi alanında da önemli çalışmaları bulunan Hârizmî̀nin, yukarıda da ifade edildiği üzere, felsefeye yönelik bir ilgisi ya da bilinen bir eseri yoktur. Döneminin ilim merkezi olan Bağdat'taki Beytülhikme'de aktif olarak görev almış ve ilmi çalışmalara katkıda bulunmuştur. Onu dünya ölçeğinde bir deha olarak tanımamızı sağlayan çalışmaları matematik alanında olmuştur. Onluk tabanlı sayma sistemini matematiğe kazandıran Hârizmî'dir. Avrupa'da yıllarca ders kitabı olarak okutulan, bugün bildiğimiz cebrin isim babası olarak anılmasını sağlayan eseri ise el-Kitâbu'l Muhtasar fî Hisabi'l Cebr ve'l Mukâbele' dir. Bu çalışma, kaleme alınmasının ardından on iki yüzyıl sonra bugün, içinde yer aldığım bir ekip tarafından, açıklayıcı metinler eşliğinde Cebir ve Denklem Hesabı Üzerine (Bkz.: Hârizmî, 2021) başlığıyla günümüz Türkçesine ilk kez kazandırılmıştır.

Hârizmînnin Cebr'in girișinde anlattığ (Abbasi dönemi) halifesi olan Me'mun kendisinden halkın gündelik meseleleri çözerken karşılaştığı sorunları giderecek, basit bir anlatımla halkın kolayca anlayabileceği bir matematik kitabı yazmasını ister ve o da bunun üzerine şaheserini kaleme alır.(Hârizmî, 2021, s. 78; Muhammad ibn Musâ Khowarizmi, 1831, s. 3) Bu şaheser, Cebr, halifenin isteğini karşılayacak şekilde halkın anlayacağı düzeyde basit ve gündelik sorunların çözümüne dair örnekleri içeren pratik bir matematik kitabı olmakla birlikte, Hârizmînnin kendi dehasını kanıtladığı teorik bir matematik kitabı olma özelliğine de sahiptir. Bu itibarla, hem "herkes için matematik" hem de " matematik için matematik" anlayışlarının her ikisini de aynı kitapta bir araya getirdiği söylenebilir. Temel olarak iki ana başlıkta incelenebilecek kitabın ilk bölümü, Hârizmî'nin teorik matematiğini anlattığı ve sayılara dair bir tasnif verdiği kısımdır. Burada, hesaplama mevzularına bir giriş yapar ve "sayıya eşit olan kökler ve kareler", "köke eşit olan kareler ve basit sayılar" ve "kareye eşit olan sayı ve kökler"e ilişkin açıklamalarını sunduktan sonra bunların her birinin, kareye tamamlayarak ya da indirgeyerek modelleme yoluyla geometrik ispatlarını verir. Ardından bu sayılar, kökler ve karelerin toplama, çıkarma, çarpma ve bölme işlemlerini ve bunlarla kurulacak denklemleri örnekleriyle anlatarak ilk bölümü tamamlar. Buraya kadar olan kısım, Hârizmî'nin teorik matematiğini “özet” olarak anlattığı kısımdır. İkinci kısım ise Halife Me'mun'un kendisinden istediği "gündelik meselelerin basit çözümlerini” teorik kısımda anlattığı yöntemlerle çözdüğü "Vasiyetler Kitabı” ile başlayan kısımdır. Bu kısımda, vasiyet, alım-satım, borç ve ticarete dair karşılașılacak muhtemel sorunlar ve bunların matematiksel çözümlerine yer verir. İkinci kısım, yalnızca bir matematik örnek çözümler kitabı değil aynı zamanda dönemin toplumsal yapısını ve gündelik sorunlarını yansıtan tarihi bir vesika ve bunların çözümlerini konu edinen bir diğer disiplin olan İslam Hukuku açısından önemli bir kaynak niteliğindedir.

Cebr, baştan sonra, teorik ve uygulamalı matematiğin örneğini sunan bir matematik kitabıdır. Ancak hiçbir matematiksel sembole kitap boyunca yer verilmemiştir. Cebirsel denklemlerin geometrik ispatlarında kullandığ şekiller dışında, tamamıyla retorik bir anlatıma sahiptir. $\mathrm{Bu}$ özelliği bugün için bir matematik kitabı olarak okunmasını zorlaştırsa da, soyut düşünme açısından zihni, sınırlarına dek aktif olarak kullanmaya teşvik eder niteliktedir.

Hârizmî ve Cebr'e dair genel bir malumatı içeren bu giri- 
şin ardından, bu çalıșmanın amacı olan Hârizmî cebrini metafizik ve semantik olarak incelemeye yardımcı olması açısından matematik ve metafizik arasındaki ilişkiye bir alt başlıkta değinilecektir.

\section{MATEMATIK VE METAFIZIIK ${ }^{1}$}

Bugün en matematik bilmeyenimizin bile matematiğe dair algısı onun son derece bitimsiz ve çetrefilli olduğunu kavrayacak düzeydedir. Karmaşık formüller bir yana, pek çoğumuz sayı kümelerinin neler olduğuna dair yeterli bilgiye sahip değilizdir. Esasında, küme kuramları dahil olmak üzere matematikte yaşanan bu muazzam genişleme ve derinleşmenin son iki yüzyılda hız kazandığı bilinmektedir. Oysa sayıların bu kadar karmaşık olmadığı, matematiğe dair tüm bilginin bir cetvel ve pergel mesabesinde olduğu zamanlarda dünyaya dair algımız ve bilgimiz de bu denli sınırlıydı. Örneğin "Bir Yunanlı geometrik bir yapıdan bahsettiğinde, cetvel ve pergelle meydana getirilen bir yapıyı kastetmekteydi. Bunlar tanrının aletleriydi; diğer yolların hiçbiri filozofun uğraşmasına değer bulunmuyordu."(Dantzig, 2011, s. 109) Tanrının evreni var ederken kullandığı araçlar olan cetvel ve pergelin sınırı, insanoğlunun bu evreni anlama çabası için de yeterli sınırlardı. Bu sınırlar içinde kalarak yaşamsal ihtiyaçlara karşılık bulabilmek mümkündü. Zira matematik, bugün olduğu gibi kendi için değil, yaşamın zaruri ihtiyaçlarına cevap verebilmek içindi: "Bir işe yaramak matematiğin ilk varoluş sebebi. Sayılar kullanışlı çünkü saymaya ve ticaret yapmaya yarıorlar. Geometri dünyayı ölçmeye, cebir de günlük hayatın problemlerini çözmeye yariyor."(Launay, 2016, s. 150)

Matematiğin, deyim yerindeyse, rüştünü ispat etmesi yolunda aşılan ilk eşiklerden biri Thales teoremleri ve diğeri Pisagorcuların ağza alınmasını dahi yasakladığı oransız öğeler olan alogondur. Thales teoremine göre çap, çemberi iki eş parçaya böler. Bu, çizenden ve çizildiği yüzeyden bağımsız olarak çemberin bir varlığa sahip olduğu anlamına geliyordu. Yani çember, kendi elimizle bizim dışımızda yarattığımız bir nesne değildir.

"Thales cini şişeden çıkarıyor. Bir çember alın, istediğiniz herhangi bir çemberi alın, hangisi olduğunu bana söylemeyin. Devasa veya ufacık olabilir. Yatay, dikey veya eğimli bir düzlemde çizin, fark etmez. Çizdiğiniz çemberi nasıl çizdiğinizi de bilmiyorum. Fakat yine de diyorum ki çemberinizi kesen çap onu iki eşit parçaya böler!

Bu işlemle Thales geometrik şekillere kesin olarak soyut matematiksel nesne statüsü veriyor. Düşünce dünyasının bu aşaması, iki bin yıl Mezopotomyalıların sayıları sayılan nesnelerden bağımsız olarak düşünmüş olmalarına benziyor. Çember artık sadece

Bu alt başlık, Cebir ve Denklem Hesabı Üzerine Özet Kitap'ta yer alan "Çağdaş Felsefe ve Nesne Kuramı Tartışmaları Bağlamında Hârizmî̀nin Cebri” başlıklı yazımızdan aktarılmıştır. Tuğba Yavuz, "Çağdaş Felsefe ve Nesne Kuramı Tartış maları Bağlamında Hârizmînin Cebri”, Cebir ve Denklem Hesabı Üzerine Özet Kitap, s. 53-62. toprağın üstüne, tablete veya papirüse çizilmiş bir şekilde değil. Çember, tüm gerçek temsilleri ancak kusurlu birer canlandirma olan bir kurgu, bir fikir, soyut bir ideal haline geliyor. "(Launay, 2016, s. 65)

İkinci olan ise, karenin köşegenine oransal olmadığının keşfidir. Kenarları bir birim olan bir karenin köşegeni birimdir. , o zamana kadar varlığından haberdar olunmayan bir sayıdır, zira sayı ya da matematiksel nicelikler, daha önce de ifade edildiği gibi, cetvel ve pergelle ölçülebilen, diğer bir ifadeyle bireyleştirilebilen büyüklüklerdir. Bugün irrasyonel sayılar olarak bildiğimiz ve gibi sayılar, bireyleştirilebilen nicelikler olmadığı için Pisagorcuların izah edemediği ve evren-sayı ilişkisinde bir yere oturtamadıkları matematiksel keşiflerdir.

"Karenin köşegeni, kenarına oranlı değildir. Bunu ilk kimin ve nasıl keşfettiği muhtemelen sonsuza kadar sır olarak kalacaktır. (...) Fakat kim keşfetmiş olursa olsun, Pisagorcuların saflarında büyük şaşkınlık yarattığı su götürmez. Bu öğelere verilen adın kendisi de bunu doğrular. Bu oransiz öğelere alogon, "ă̆za alınamayanlar" adı verilmiş ve mezhep üyeleri bunların varlıklarını yabancılara açmamaya yemin etmiştir. Mimar'ın [Tanrı'nın] eserinde açıklanamayan bir kusur ifşa edilmiştir, gazabının insanlara yönelmemesi için son derece gizli tutulması gereken bir kusur.

Proclos diyor ki:

Denir ki bu irrasyonel sayıları saklandıkları yerden ilk kez açı̆̆a çıkaranların hepsi deniz kazasında yok olmuştur. Zira ăgza alınamayanlar ve biçimsizler gizli tutulmalıdır. Hayatın bu suretini ifşa edip ona dokunanlar derhal helak edilmiştir ve sonsuza dek ebedi dalgaların oyununa maruz kalacaklardır."(Dantzig, 2011, ss. 98-99. Alıntıdaki parantezler bana aittir)

Matematiğin ya da geometrinin nesnelerinin kendi başına varlık sahibi olması ya da bilinen ölçme/sayma yöntemleriyle ölçülebilir/sayılabilir olmayan sayıların var olması neden rahatsızlık unsuru olsun? Çünkü nesne ya da varlığa dair tanımlamalar, somut ya da somuta indirgenebilir, somut olanla eşleşebilir niteliklere sahipti. Platon'un ideaları bile somut gerçeklerle mütekabiliyet içinde düşünülen varlıklardı. Diğer bir ifadeyle, evreni yöneten ya da her şeye içkin töz olarak benimsenen şey maddesel olmasa bile, maddesel olanla izdüşüm halinde düşünülüyordu. Yüzylllarca hüküm süren Aristoteles mantığ 1 da fizik dünyayla izdüşümselliğe izin veren, dahası bunun dışına çıkmaya izin vermeyen bir yapıya sahipti. Matematiğin nesnelerinin fizik dünyanın sınırlarını aşmamış olması, düşüncenin yani felsefe ve mantığın maddesel olanla sınırlı kalması için gerekli konfor alanını sağlıyordu.

"Matematik ve fizik arasında kurulan bu ilişkinin doğasını iyi anlamak gerekiyor. Çünkü daha önce tarihimizin başlangıcından beri şahit olduğumuz gibi matematik 
dünyayı araştırmak ve anlamak için kullanılmış. Fakat 17. yüzyılda köklü bir yenilik gerçeklești. O zamana kadar matematiksel modellemeler hâlâ insani yapılar alanındaydl, gerçeğin üzerine çizilmiş ama gerçek tarafından yaratılmamış yapılar olarak değerlendiriliyordu. Mezopotamyalı geometriciler geometriyi insanlar tarafindan çizilmiş olan dikdörtgen tarlaları ölçmek için kullanıyordu. Çiftçi oraya çizmeden önce dikdörtgen doğaya ait değildi. Aynı şekilde, coğrafyacılar harita yapmak için bir bölgeyi üçgenlediklerinde düşündükleri üçgenler tamamen yapaydr."(Launay, 2016, s. 172)

Bahsi geçen 17. yüzyılda gerçekleşen köklü yenilik Newton'un matematikten yararlanarak yerçekimi yasasını bulmasıdır. "Matematik tarihinin ilk krizine" sebep olan "nispeten basit iki problem -karenin köşegeni ile dairenin çevresinin hesaplanması- rasyonel alan içinde hiçbir yer bulunamayan yeni matematiksel varlıkların mevcudiyetini ortaya çıkarmıştır.”(Dantzig, 2011, s. 127) Matematiksel nesnelerin müstakil varlıklarının kabulünün ardından 17. yüzyıl ve sonrasına tekabül eden dönemde fizikte yaşanan gelişmeler ve peşi sıra gelen evrene dair matematiksel çözümlemeler, matematiğin sınırlarının fizik dünyayla çizilemeyeceğini; bilakis, fizik dünyanın sınırlarının anlaşılmasında hatta aşılmasında matematiğin hayati bir role sahip olduğunu bir kez daha kanitlar.

Matematikte bu gelişmeler yaşanırken, felsefede de kadim varlık tartışması boyut değiștirerek sürdürülmekteydi. Kimi zaman varlığın hakikatinin düșünülür (yani soyut; Platon, Yeni Platoncular) kimi zaman da duyulur (yani somut, Aristoteles'ten Kant ve sonrasina dek) olanda aranması gerektiği savunulurken, tarihler Aydınlanma dönemini gösterdiğinde, bilimde yaşanan gelişmelerin de etkisiyle, felsefenin metafizikten arındırılması ve bilimsel bir yapıya bürünmesi düşüncesi güçlenmeye başladı. Başlıca temsilcileri Viyana Çevresi ve Analitik Felsefe Geleneğine dahil filozoflar olan bu düşünceye göre, dili metafizik unsurlardan arındırmak ve gramatik yüklemlerle mantıksal yüklemleri birbirinden ayırmayı sağlayacak yeni bir felsefe dili yani yeni bir mantık oluşturmak gerekti. Bu amaçla oluşturulan, G. Frege'nin (ö.1925) öncülük ettiği sembolik mantık, gramatik yapıyla mantıksal yapıyı ayırmada daha başarılı olsa da metafiziği sınır dışı etmeye yeterli olmamıştır. Yaklaşık tarihlerde felsefe dünyasında öne çıkan bir diğer düşünce, Franz Brentano'nun (ö. 1917) yönelimselliği temelinde Alexius Meinong'un (ö. 1920) Nesneler Kuramıdır(Meinong, 1960). Buna göre, değil metafiziği kapsam dışı bırakmak, klasik metafizik anlayışı aşarak yalnızca soyut ya da somut (yani tam belirlenmiş; örneğin, önümde duran matematik defterim, defterde yazılı formüller ve bir formülün sonucu olan sayının kendisi -diyelim ki, 3 ya da-) nesneleri değil, varolmayan nesneleri (yani tam belirlenmemiş/eksik belirlenmiş nesneler, örneğin pegasus) ve hatta çelişik nesneleri (örneğin, yuvarlak kare) de içerecek yeni bir nesne kuramının geliştirilmesi gerekir. Brentano'nun yönelimselliği, zihnin yöneldiği her şeyi bir nesne olarak tanımayı mümkün kılan bir anlayışın kapısını aralar. Zihin bir şeye yöneldiğinde, o şeyin soyut ya da somut, tam ya da eksik belirlenmiş olmasına bakmaksızın ona yönelir ve nesneleştirebilir.(Brentano, 2009, s. 68) Meinong da bu anlayıştan yola çıkarak nesne olabilmenin temel koşulunun varolmak ya da herhangi türden bir varlık kipine sahip olmak olmadığını iddia eder. Somut ya da soyut bir varlığa (Sein'a) sahip olsa da olmasa da nitelikleri (Sosein'ı) üzerinden bir şeyi tanımak ve ona dair bilgi üretmek mümkündür. Tıpkı gerçek hayatta varolmayan Pegasus ya da Sherlock Holmes hakkında bilgi sahibi olduğumuz gibi. Meinong bu düşüncesini, çelişik olanı da içerecek şekilde genişletir. Zira, ona göre, zihin çelişik olana da yönelebilir ve nitelikleri üzerinden bilgi nesnesi haline getirebilir. Yani, yuvarlak kare olarak betimlenen bir şey, zihnin yöneldiği bir nesne olarak nesne kuramında yerini alabilir.

Meinong'un Nesne Kuramı başta B. Russell (ö. 1970) olmak üzere, bu kuramın temel mantık ilkelerini ihlal ettiği gerekçesiyle, pek çok çağdaşı düşünür tarafından eleştirilmiştir. (Russell'ın Meinong'a bu yöndeki eleştirileri için örneğin bkz. : Russell, 1904. Ayrıca bu metninden sonra aynı başlıkla (II) ve (III) olarak yayınlanan yazılara da bakılabilir.) Fakat ilerleyen zamanlarda mümkün dünyalar anlayışı ve bu dünyaların içerdiği nesnelerin semantiğini yapmayı olanaklı kılacak bir modal mantığın Saul A. Kripke (d.1940) öncülüğünde geliştirilmeye başlanmasıyla Meinong'a hak verenlerin sayısı çoğalmıştır. Mümkün dünyalar, tam da Meinong'un bahsettiği şekilde, bu dünyada herhangi bir varlığı olmayan fakat mümkün bir dünyada düşünülebilir ve hakkında yargıya varılabilir türden olan nesneleri içerir. Modal mantık sayesinde de, bu nesneler hakkında anlamlı bir şekilde önermeler dile getirilebilir ya da bir diğer ifadeyle, mümkün nesnelere dair önermelerin semantik değerlerine ilişkin çıkarımda bulunulabilir. Dahası, mümkün dünyalar fikrinden hareketle, imkansız dünyalar düşüncesi de kendisine yer bulmuş ve yine modal mantığın uygun şekilde geliştirilmesiyle yuvarlak kare türünden imkansız nesnelerin semantiğine de kapı aralanmıştır.

Varlık düşüncesinde, cetvel ve pergelle ölçülebilenin dışına çıkılamazken, yüzyıllar sonra imkansız nesneyi dahi içerebilecek anlayışlar gelişmesini sağlayan saik/ler nedir ya da nelerdir? Elbette matematikte yaşanan gelişmelerdir. 20. yüzyılda Georg Cantor (ö.1918), kümeler kuramını oluşturarak bugün bildiğimiz anlamda sayı kümelerini (doğal sayılar kümesi, tam sayılar kümesi, rasyonel sayılar kümesi vs.) tanımlamıştır. Bu kuramın en önemli katkısı, sonsuza ilişkin açıklamalarıdır. Sonsuz kümeler ve sonlu ötesi sayılara dair iddiası gerek matematikte, gerekse düşünce dünyasında yeni bir çı̆̆ır açmıştır. Çok özet bir şekilde ifade edilecek olursa, sonsuz kümeler ve sonlu ötesi sayılar fikrine kümelerin sıralı çiftlerinin bire-bir eşlenebilirliği üzerinden ulaşmıştır. Herhangi iki küme, örneğin doğal sayılar kümesi ve tam sayılar kümesi veya doğal sayılar kümesi ve bunun alt kü- 
melerinin kümesi bire-bir eşlenebilir sonsuz büyüklükte kümelerdir. Ancak reel sayılar kümesi doğal sayılar kümesi ile bire-bir eşlenebilir değildir. Doğal sayılar kümesi üzerinde seçili bir aralıkta, önceden tanımlanmış belirli adımlar takip edildiğinde seçili aralıkta olmayan bir sayı, Cantor'a göre, her zaman türetilebilir. Bu da, reel sayılar kümesinin doğal sayılar kümesinden daha fazla kardinale sahip olduğunu gösterir. Her ikisi de sonsuz kardinaliteye sahip kümeler olsa da, reel sayılar kümesi daha büyük bir sonsuzluğu ifade eder. Reel sayılar kümesinin alt kümelerinin kümesi de reel sayılar kümesinden daha fazla kardinale sahip olacağından, reel sayılar kümesinden de büyük sonsuz kümelerden bahsetmek mümkün hale gelir. Bu durumda, sayllabilir sonsuz kümeler (örneğin doğal sayılar kümesi ya da reel sayılar kümesi) bir yana, sayılamaz sonsuz kümeler (reel sayılar kümesinin alt kümelerinin kümesi, alt kümelerinin alt kümlerinin kümesi vs.) de varlık kazanmış olur. Böylece Cantor, sonsuzun kendi içindeki hiyerarşisini matematiksel olarak kanıtlamıştır. "Her tutarlı (yani modeli olan) teorinin sayılabilir bir modeli olduğunu" söyleyen Löwenheim-Skolem teoremine göre "eğer bir formül sağlanabiliyorsa, sayılabilir bir alan içinde de sağlanabilirdir."(Therrien, 2012, s. 31) Yani, sayılabilir sonsuz bir kümenin herhangi bir bireyi ile tutarlı bir model içindeki sayılamaz sonsuz kümenin bir bireyi aynı muameleyi görebilir.

Meinong'un Nesne Kuramının geçerlilik kazanması ve imkânsız dünyalar fikrine dek genişleyen felsefe ve mantık sistemlerinin geliştirilmesinin arka planında matematikte yaşanan bu muazzam açılımlar yer alır. Eğer matematiksel olarak "sonsuz" kanıtlanmış ya da bir temele oturtulmuş olmasaydı, sonlu ötesi sayılar ve kendi içinde bir hiyerarşiye sahip sonsuz büyüklükte kümeler matematiksel zemin üzerinde varlık kazanmamış olsaydı, nesne kuramlarından da, mümkün ve imkânsız nesnelerin mantıksal ve metafiziksel varlığından da bahsetmek söz konusu olmayabilirdi.

"Tarihte, 20.yy boyunca doğa bilimi muazzam bir değişim geçirdi: bunun matematiksel yorumu, bu değişimin ontolojik olmasının arkasındaki itici güçtü. Deterministik fizik yasasının dilini, olasılıklar gibi daha az kesin bir şeye dönüştüren bilim insanları var, fakat determinizm, araştırmanın gerçek amacını yani keşfi engelliyor. Olay uzamını (doğal dünya) mekanik bir bakış açısından incelemek artık mümkün değilse, o zaman diğer olay uzamını (sosyal gerçekler) bu yollarla incelemek kesinlikle mümkün değildi. Bu nedenle, belirsizlik sorunuyla başa çıkmak için olasılık teorisi kurulmuş ve bilimin birçok alanına başarıyla uygulanmıştır."(Nasution, 2018, ss. 1-2)

Bilimde determinist fizikten olasılık teorilerine ilerleyen yolun arkasındaki itici gücün matematiksel yorumlar olması gibi, ontoloji ve metafiziğin nesnelerinin de fizik dünyadakilerle mütekabiliyet içinde olan tam belirlenmiş nesnelerden, tam belirlenmemiş ya da çelişik olan mümkün ve imkansız nesnelere dek genişlemesinin arkasındaki itici güç de matematiksel yorumlardır.

Buraya kadar olan bölümde, varlık anlayışının ve nesneye dair çıkarımların nereden nereye geldiğini genel hatlarıyla ele almaya çalıştık. Bir sonraki bölümde Hârizmî'nin, varlık ve nesneler kuramı tartışmalarının neresinde yer aldığına değinilecektir.

\section{HÂRIZMî CEBRININ METAFIZIKK VE SEMANTIK YORUMU}

\subsection{Cebr'de Nesnenin Metafiziksel Sınırı}

Hârizmî'nin felsefeye katkısının Cantor'unkine benzer bir katkı olduğunu söylemek yanlış olmayacaktır. Daha doğrusu, eğer bu tartışmalar o gün yürütülebiliyor olsaydı, düşüncenin bugün geldiği eşik o gün aşılabilir düzeye yaklaşabilirdi. Söz konusu bu benzerlik, nesnenin metafizik sınırına dair durdukları yerdir. İlerleyen satırlarda bizim kuracağımız bu benzerliğe geçmeden önce, Cantor ve Hârizmî arasında kurulan ilginç ve önemli bir başka benzerliğe de değinmek gerekir. Cantor'un matematiğe yaptığı en önemli katkılardan birinin kümeler kuramı olduğuna bir üst başlıkta değinilmişti. M. Nasution, küme kuramının ilk örneğini Hârizmî'de bulacağımıza işaret eder:

“'Küme' kavramı biçimsel olarak ne zaman tanımlandı? Bu soru henüz yanitlanmadl. Fakat 19.yy'ın sonunda George Cantor, küme kuramının kurucusu, bu kuramın başlangıcı olarak şu tanımı vermiştir: örneğin, "Bir küme, kavrayışımız ya da düşüncemizin belirli [türden] farklı tüm nesnelerinin bir araya getirilişidir." Küme kuramı, aidiyet ve gösterici/ yüklemleyici (Ing. predicator) kavramları üzerinden kümeyi özelleștiren/belirleyen bir yazım/notasyon kullanılarak kavramları biçimselleştirme yollarından biridir. Kavramsal olarak küme kuramıyla ilgili tartışma, yeterince uzun zaman önce gözden geçirilerek kanıtlanmıştır, genellikle küme kavramına yani değişkenler olarak ifade edilen bir tür soyutlamaya dayalı olan cebir, Muhammed bin Musa el-Hârizmî tarafından halihazırda geliştirilmişti."(Nasution, 2018, ss. 1-2)

Küme kuramının temelini IX. yüzyılda Hârizmî'nin atmış olup olmadığı bizim açımızdan birincil öneme sahip değildir. Ancak yine de, yalnızca başlıklarına bakarak Hârizmî'nin kendine has bir "sayı sistemi" inşa ettiğini söylemek mümkün görünmektedir. Bu sayılar, yukarıda da anılan, "sayıya eşit olan kökler ve kareler", "köke eşit olan kareler ve basit sayılar" ve "kareye eşit olan sayı ve kökler" dir. Hârizmî bütün teorik sistemini, bu üç tür ve bunların alt başlıklarının izahını vererek kurar ve anlatır. "Kümeyi özelleştiren bir yazım” yoluyla "kavramların biçimselleştirilmesi” ise bir sonraki başlığın konusunu teşkil edecektir. Burada, Hârizmînnin Cebr'i inşa ettiği dil ve dayandığı metafizik temel ele alınacaktır. 
Cebr, Launay'a göre, Hârizmî’yi “Arşimet ve Brahmagupta'nın yanında, tarihin en büyük matematikçileri arasındaki yerini sağlamlaştıracak olan devrim niteliğinde” bir kitaptır. (Launay, 2016, s. 124) Küme kuramının henüz bahsi bile yokken, çeşitli betimlemelerle sayıları konu edinen Cebr, "bilinmeyen" kavramiyla matematiksel ve matematiksel olmayan nesneye gönderimde bulunur. Bizim açımızdan Cebr'i önemli kılan husus da budur.

Nesnenin ne olduğu ya da neyi nesne olarak kabul edeceğimiz sorunu bir "varlık" sorunudur. "Var" dediğimiz ya da var kabul ettiğimiz şeyler, ontolojimizin nesneleridir. Bir önceki bölümde değinildiği üzere, Antik dönemden 19. yüzyıla dek mütekabiliyet temelli ontolojilere bağlı kalınmış yani ister duyulur, ister düşünülür özler kabul edilsin, nesnenin sınırlarını uzam-zamansal olanla belirleyen metafizik ve ontolojik anlayışlar benimsenmiştir çoğunlukla. Brentano'nun yönelimsellik anlayışı ve bu anlayış üzerine inşa edilen Meinong'un Nesneler Kuramı ile nesnenin sınırları empirik olanı aşmaya yönelik ilk büyük adımı atmıștır. ${ }^{2}$ Bu kurama göre, empirik duyumsanabilirliğinden bağımsız olarak zihnin yöneldiği her şey nesnedir. "Varolmak" nesne olmanın koşulu değildir. Bu dünyada bilfiil varolmasa, tam belirlenmiş bir nesne olarak tanımlanamasa da, zihnin yöneldiği her şey bir kendiliğe (Sein'a) sahiptir ve oldukları haliyle bulunuşlukları (Sosein'ı) vardır, mevcut nitelikleri üzerinden bilgi nesnesi haline getirilebilirler. Zihin, elimde tutmakta olduğum kitaba da, televizyonda beliren daha önce hiç görmediğim herhangi bir nesneye de, kitapta ya da televizyon ekranında gördüğüm piramite de, hiç görmediğim, sesini hiç duymadığım bir unicorn ya da Sherlock Holmes'e de aynı şekilde yöneliyor. Bu durumda, içinde bulunduğumuz fizik dünyada varolmayan ancak mümkün bir dünyada varlığı düşünülebilecek olan şeylerin nesneler kuramının meşru nesneleri olarak ontolojilerde yerini alması olanaklı hale geliyor. Öte yandan Cantor'un küme kuramı ve sonsuza ilişkin matematiksel yorumu, Löwenheim-Skolem Teoremi ile bu yorumun işlevsellik kazanması yani bireyselleştirilememiş nesnenin bir model içerisinde tanımlanarak geçerlilik kazanması, nesnenin metafizik sınırını mümkün ve imkansız nesneye dek genişletmenin matematiksel ve mantıksal zeminini hazırlamaya yardımcı olmuştur.

Üst başlıkta matematik ve bilimde yaşanan gelişmeleri de hesaba katarak, Meinong'un yönelimsellik temelli nesneler kuramının düşünceye kattıkları ışığında Hârizmî’nin Cebr'ine baktığımızda oldukça benzer bir yapıyla karşılaşıyoruz. Hârizmî cebirsel denklemlerin çözümünde, sayıyı ele alırken, doğrudan sayının kendisinden bahset-

\footnotetext{
Ne yönelimsellik anlayıșı ilk kez Brentano tarafından dile getirilmiş ne de empirik tecrübenin dışında kalanlar ilk kez Meinong tarafından nesne olarak kabul edilmiştir. Felsefe tarihi boyunca her ikisinin de örneklerine rastlamak mümkündür: Eski Stoa'da olduğu gibi. Ancak yönelimsellik üzerine sistematik bir şekilde nesne kuramı inşa etmek ve bunu Aristotelesçi olmayan yeni ve matematiksel nitelikteki mantıklarla desteklemek metinde bahsettiğimiz döneme tekabül etmektedir. Öncesine ait örnekler için örneğin bkz. (Brun, 1997; Dürüşken, 2013; Yavuz, 2020, ss. 164-171)
}

meksizin onu farklı șekillerde betimleyerek yani farklı nitelikleriyle ya da aynı sonuca götüren farklı işlemsel bağıntılarıyla ondan bahsederek herhangi bir sayıyı konu edinebilmektedir. Örneğin, kendi kullanmış olduğu şu betimlemelere bakarsak:

\section{"kare dokuza eşittir, bu bir karedir, onun kökü de üçtür"}

"bir kare ve sayllardan yirmi bir, (bu) karenin on köküne eşittir. Bunun manası, yani kendisine yirmi bir dirhem eklendiğinde bu karenin on kökünün eşitine denk gelen kare"

Burada bahsedilen her iki sayı da üçtür.

"üç kök ve sabit sayılardan dört, bir kareye eşittir"

"karenin beş katı seksendir. Bir kare, seksenin bește biridir"

\section{"kendisinden üç kökü çıkarıp sonra kalanı kendisiyle çarptığında geri elde ettiğin kare”}

$\mathrm{Bu}$ örneklerde bahsedilen sayı ise on altıdır. (Yavuz, 2021, s. 64) Bugün için çözümü son derece basit olan bu türden cebirsel denklemlerle doludur kitap. Cebrin metafiziksel temeli olarak düşündügüümüz ve dikkat çekmek istediğimiz husus, Hârizmî'nin basit (sabit) sayı, kare ya da kök olarak sayılardan bahsetme ya da onları betimleme yoludur. Örneklerdeki sayı olan üç ya da on altının kendisinden hiç bahsetmeksizin bu sayılara dair betimlemeler yapmış, niteliklerinden ve sahip oldukları kimi bağıntılardan hareketle onları tanımlamıştır. Bu bize, Hârizmî’nin yöntemiyle, hakkında henüz bir bilgimiz olmasa da tanımlamalar ya da betimlemeler yoluyla nesnenin kendisine ulaşabileceğimizi ya da kendisine dair bilgi edinebileceğimizi matematiksel olarak gösterir. Örnek ifadelerde bahsedilen sayı, bilinen bir sayı olmakla birlikte, aynı yöntem kullanılarak hiç bilinmeyen ya da bireyleștirilemeyen sayılardan bahsetmek, bu türden sayıları işlemlere dahil etmek de pekala mümkün görünmektedir. Zira Hârizmî'nin kök olarak bahsettiği kavram Arapça "şey" kelimesiyle karşılığını bulan ve günümüz matematiğinde " $x$ " değişkeni ile ifade edilen şeydir. " $x$ " bilinen değişken bir sayı olabileceği gibi, bilinmeyen bir sayı da olabilir. (Şener Öztürk, 2021, s. 38) Doğası gereği, bilinmeyen sayı, her türlü sürprize açık olarak, bildiğimiz sayı kümelerinin elemanlarından biri olma özelliğine sahip olamayabilir. Yani, bu dünyanın bilfiil nesnesi olmayan mümkün ya da imkansız bir nesne yerine duruyor olabilir. Launay, "problemlerin çözüm işlemlerini problemlerden bağımsız ayrıntılandırdığı" ve kullandığı yöntem "sayısal verilere bağlı olmadığı için” Hârizmî̀nin içeriğini ve yöntemini "devrimci” olarak nitelendirir. (Launay, 2016, ss. 124-127)

Hârizmî'yi taklitle, şöyle bir denklem kurarak sayıdan bahsetmeye çalışalım:

"Kendisiyle çarpımının on fazlasının üç ile bölümü 
dört eden sayı. (Matematiksel olarak şöyle gösterilebilir:)

veya,

Kendisiyle çarpımının beşfazlası, kökünün üç katıdır. (Matematiksel olarak şöyle gösterilebilir)"(Yavuz, 2021, s. 66)

Bu denklemlerden ilkinin çözümü 'dir ve ikincisinin reel bir kökü yoktur. O halde, Hârizmî'nin yöntemini kullanarak varolan bir sayıdan ya da nesneden bahsedilebileceği gibi, varolmayan bir sayıdan ya da nesneden bahsetmek de mümkündür. Burada önemli olan soru, bunu yapabilecek sistemi inşa etmesine rağmen Hârizmî̀nin neden bunu tercih etmediğidir. İrrasyonel sayılardan da, negatif sayılardan da haberdar olan ve bunlarla işlem yapabilecek matematiksel bilgiye pekala hakim olan Hârizmî, denklem çözümlerinde bu sonuçlardan kaçınmış, denklemlerin negatif köklerini bulmamış, hesaba dahil etmemiştir.(Şener Öztürk, 2021, s. 39) Bu durum bize, onun metafizik anlayışına dair ihtiyacımız olan ipucunu verir. Hârizmî'nin ontolojisinde yalnızca varolanlar vardır. Varolan bir nicelik negatif büyüklükte olamayacağından onun varlık alanı içinde yer almaz ve nesne kategorisine dahil edilmez. Hârizmî üzerine önemli çalışmaları bulunan R. Rashed'in (d.1936) Hârizmî̀nin "şey" kavramını hem rasyonel hem de irrasyonelleri kapsayacak şekilde kullanarak biçimsel bir ontoloji geliştirdiğini aktaran Tahiri, onun ontolojisiyle ilgili şu yorumu yapar:"3

"Bir sayı aynı zamanda irrasyonel de olabileceğinden, "şey" yalnızca yaklaşık olarak bilinebilen bir niceliği belirtir. Buna göre cebircilerin konusu, geniş bir içerik yelpazesini alacak kadar genel olmalıdır; fakat dahası, yaklaşımı geliştirmesinin her zaman mümkün olabilmesi için kendi belirlemelerinden bağımsız olarak var olmalıdır. Aristotelesçi teori, böyle bir nesnenin ontolojik statüsünü net bir biçimde açıklayamaz. Dolayısıyla, karakterden yoksun bir nesneden söz etmemizi ve bununla birlikte onun soyutlamasının ne olduğunu ayırt etmemizi sağlayacak yeni bir ontoloji geliștirilmelidir; bir nesneyi tam olarak temsil edemeden de bilmemizi sağlaması gereken bir ontoloji."(Tahiri, 2016, ss. 22-23)

Metafiziği empirik olanla sınırlı olan Aristoteles, sayı ve varlık arasındaki ilişkiyi kurmakta yetersiz kalmıştır. Ona göre, maddi tözden yoksun olanların, yani örneğin "matematiksel şeylerin" ayrı başına cevherler olarak tanınmasının imkanı yoktur.(Aristoteles, 1996, s. 592 [1090a/25, XIV. Kitap]) Dolayısıyla, Aristoteles ontolojisinde nesnel olanla ilişkisi kurulamayacak olan irrasyonel sayılar (cetvel ve pergelle ölçülemeyecek büyüklükler) yer bulamamıştır.

"Yunanlılar, irrasyonel sayıların varlı̆̆ını göstererek büyük ustalıklarını kanıtladılar, ancak soruna çözüm, yalnızca ve basit bir şekilde, onları keşfeder keşfetmez oybirliğiyle

\footnotetext{
Farabi, Ibn-i Sina ve Harezmi bağlantısı için ayrıca bkz:: Yavuz, 2020, s. 113 vd.
}

reddetmek ve geometrinin aritmetik bölümünü, böylece bağımsızlık statüsünü yitirmek oldu. Bu bağlamda, 9. yüzyılın başlarında Muhammed ibn Mūsā al-Khwārizmī Yunanlıları şok etmiş gibi görünen keşifle uğraştlğında meydana gelen epistemik devrim fark edilebilir. Kitâbü'l-Cebr ve'l-Mukâbele'de, diğer șeylerin yanı sıra, irrasyonel sayıların, rasyonel sayllarla aynı aritmetik kurallara uyduğunu göstererek, sayı kavramını genişletti.” (Tahiri, 2016, s. 26)

Burada Aristoteles ve Hârizmî arasındaki önemli ayrıma dikkat çekmek gerekir. Hârizmî, irrasyonelleri bilir, kabul eder ve işleme dahil eder. Aynı şekilde negatif sayıları da bilir ve bunları da işleme dahil edebilir. Cebr'de verdiği bir örnekte, "Köklerin sayısını yarıladığında ve yarıyı kendisiyle çarptığında, eğer elde ettiğin, kareyle ilgili dirhemlerin sayısından azsa, örnek imkânsızdır (...)"(Hârizmî, 2021, s. 83) der. Burada "imkansız" olarak kendisinden bahsettiği kök, denklemin negatif kökü yani bir negatif sayıdır. Dolayısıyla, Hârizmî negatif sayıları bilir ve işlemlerde kullanılabildiğinin farkındadır, ancak tercih etmez. Bunun yerine onun temayülü, Cebr'de görebildiğimiz kadarıyla, negatif köklere bulaşmadan denklemin çözümünü bulmak yönündedir. Bunu ise, geometrik modellerle ispatlar yoluyla yapmıștır. O halde, Aristoteles'e kıyasla Hârizmînnin yaklaşımı söz konusu bu sayıları kabul etmeyiş ya da kökten bir reddediş değil, bilinçli bir tercih etmeyiştir. Bu bilinçli tercih etmeyiş de, metafiziğinde maddesel olmayana değil, pozitif s1nırlar içinde (yani bu dünyada bilfiil varolanlar arasında) bireyleştirilebilene yer verdiğine dair kanıt sunar.

Hârizmî̀nin geliştirdiği yöntem, Batı́nın bilimsel gelişimine başlamasından çok önce İslam bilim ve düşünce dünyasını aydınlatmış ve tüm dünyaya referans olacak şekilde gelişimine katkı sağlamıştır. "Hârizmî cebrinin varolduğu bir dünyaya doğan ve onun sağlamış olduğu matematiksel alt yapı üzerine kendi düşünce sistemlerini inşa etme imkanı bulan Farabi (ö.950) ve İbn-i Sina (ö. 1037) matematik ve geometrinin nesnelerini zihnin yönelimsel ediminin müstakil nesneleri olarak kavrayabilmişlerdir." (Yavuz, 2021, s. 69) Diğer bir ifadeyle, varlığ bilfiil varolanla sınırlandırmamışlardır. Her varolanın bir mahiyete sahip olduğu ancak her mahiyetin varolmadığı anlamını barındıran varlık-mahiyet ayrımı bu düşünce biçiminin bir ürünü olarak değerlendirilebilir. ${ }^{5}$

“İbn Sina'nın epistemolojisi, el-Hârezmî̀nin Cebir Kitabı'nın getirdiği büyük değişikliğin belirtisidir;

\footnotetext{
Ibn-i Sina'nın matematik ve geometrinin nesnelerine ilişkin açıklamaları için ise örneğin bkz. Ibn-i Sina, 2017, ss. 93, 107 vd.; Farabi'nin geometrinin nesnelerini ve genel olarak nesnenin özelliklerini anlamadığı yönünde Aristoteles'i açıkça eleştirdiği bir metin için örneğin bkz. Türker-Küyel, 1992, s. 12; Yavuz, 2021, s. 69. Farabi'nin sayıya dair açıklaması için örneğin: “Matematikçi, kategorilerden, kesinlikle hiçbir şeye yüklenmeyen işaret edilir duyuluru ve bu işaret edilir olan şeyi incelemez; bu işaret edilire ve bu işaret edilir olan şeye eklenmeleri ve ilişmeleri bakımından nicelik türlerini incelemez; aksine o türleri zihinde bu işaret edilirken ve işaret edilir olandan soyutlayarak inceler." [15]/5 75.

Vücûd-u zihni ve vücûd-u harici anlayışları da bunun gibidir. Kimi varlıklar (vücûd-u zihni) yalnızca zihinde vardır, kimi (vücûd-u harici) ise zihnin dışında yani uzam-zamansal olarak vardır.
} 
bu onu, niyetin doğası gereği, kendisine yönelinen nesneyi sonsuza kadar ilişkilendirerek aşmanın zihnin doğasında olduğunu tespit etmeye sevk eder ve yinelenme, yani ayn epistemik zihinsel edimin tekrarı, en basit ilişkilerden sadece biri olarak ortaya çıkar, çünkü insan zihninin güçlü yaratıcıllğı, ilişkiler üzerinden tümevarım yoluyla akıl yürüterek daha karmaşık ilişkiler kurabilir."(Tahiri, 2018, s. 308)

İslam düşünürlerinin, metafiziği, kurucusu olan Aristoteles'i aşacak şekilde kavrayışlarında Hârizmî cebrinin katkısı vardır. Matematiğin nesnelerinin zihnin yönelimsel ediminin bir ürünü olduğu ve tekrar eden ardıllığın sayıyı sonsuza dek türetme imkanı sunan yorumu, varlığın metafizik sınırlarına ışık tutmuştur. Sınırları genişleyen bir metafizik anlayış elbette sınırları genişleyen bir ontolojinin imkanını verir. Diğer bir ifadeyle, nesneye dair kabulümüzün önündeki empirik eşiği aşmak mümkün hale gelir. Hârizmî ve onun sşık tuttuğu İslam filozofları imkansız değilse de, mümkün nesnenin nesne kuramında içerilmesinin yolunu açmıştır. Ancak bugün bildiğimiz şekilde mümkün ve imkansız nesnenin "mantıksal bir zemin" eşliğinde sorgulanır hale gelmesi yaklaşık olarak on bir asra daha ihtiyaç duyacaktır.

\subsection{Cebrin Semantiği}

Cebr'in çevirisinde oldukça ilginç olan detaylardan biri, Hârizmî'nin cebirsel denklemlerin çözümünde geometrik modelleri takip ederek kareye indirgeme ya da tamamlama yoluna gitmesidir. Kitapta bu hususa dikkat çeken B.Ş. Öztürk, Hârizmî’nin denklem çözümünde hiç bileşik kesir kullanmamasını, denklemi geometrik bir model üzerinden çözme çabası ile açıklayarak şu şekilde anlatır:

"Örneğin gibi bir kesir çıkmışsa işlem adımlarında onu olarak alır. Yani bu kesrin anlami, 7 bütün ve bir yarımdır. Hatta öyle ki bileşik kesirle yapılması zorunlu işlemlerde bile mutlaka tam sayılı kesirleri kullanır. Örneğin "Sayıya Eşit Olan Kökler ve Kareler" başlığında gibi bir denklemin çözümünde: "Kökü ikiye böl; iki ve bir yarım olur. Bunu kendisiyle çarp, altı ve bir çeyrek olur" ifadesini inceleyelim. Burada kök 5'tir. Onun yarısı 'dir. Ama bunu telaffuz etmeden onun tam sayll halini' yi ifade eder. Buraya kadar, anlamlı bir dil için beklenir bir durum. Fakat onu kendisiyle çarp dediğinde bu sayının karesi alınması gerekir. gibi bir işlem için en pratik yol, onu bileşik kesir gibi düşünüp pay ve paydanın karesinin alınmasidir. olur. Fakat yine bu halini söylemeden onun tam sayılı halini ifade eder. "Altı artı bir çeyrek" biçiminde. Fakat gibi bir eșitlik doğrudan bulunabilir değildir. Daha da ilginç olanı karekök almakta ortaya çıkar. Cümlenin devamında: "Buna yirmi dört ekle, toplamı otuz dirhem ve bir çeyrek olur. Bunun karekökünü al, o da beş ve bir yarım olur” der. Yani 'dir. Bu işlemi doğrudan yapma şansımız hiç yoktur. Mutlaka biçiminde yaptıktan sonra onun tam sayılı kesir halini yani 'yi buluruz. Buradaki bileşik kesirleri izah etmeyişinin ana amacının, her sayıy anlamı ya da modeli üzerinden sözel olarak ifade etme çabasi olduğu düşünülebilir. Çünkü 'nin modeli ancak onu 'ye çevirdikten sonra kurulabilir. 5 bütün ve bir yarım olarak.”(Şener Öztürk, 2021, ss. 45-46)

Özetle, sıradan bir cebirsel denklem çözümünde ezbere takip edilebilecek basit adımları uygulayabilecek matematiksel bilgiye sahipken, Hârizmî israrla diş dünyada belirli bir yapıyı incitmek istemezmişçesine, tam kesirlerle ifade edilebilecek, tam, yarım ve çeyrek gibi bütünün bilinen parçalarına uydurma gayreti içindedir. Adeta belirli bir yapı oluşturan legoları, aynı parçaları farklı kombinasyonlarla yeniden bir araya getirerek istediğ şekli oluşturma çabası gibi. Peki, ama neden?

R. Martin, Intention and Desicion adlı kitabında bir matematikçiyle filozof bir mantıkçının çalıştıkları nesneye yönelik yaklaşımlarının farkına işaret ederken matematikçinin, kendisiyle çalışabileceği bir nesnenin olmasından mutluluk duyup "bunu başkasına nasıl modellediğini” görmenin peşine zevkle düşerken, verili olan bu nesnenin aslında ne olduğu, "içsel karakterleri ya da ontolojik statüleri" hakkında sorgulama yapmaya istek duymayacağı; öte yandan filozof mantıkçının verili nesnenin "gerçekte" ne olduğu, "yegâne olup olmadığı", "daha temel varlıklara indirgenebilir (ya da onlar açısından inşa edilebilir) olup olmadığını" sormak isteyeceğinden bahseder.(Martin, 1963, s. 3) Hârizmî'ye baktığımızda bu iki yaklaşımın her ikisini de görür gibiyiz. İnşa ettiği sistemde kullandığı sayıların ne olduğuna dair açık bir sorgulama yürütmemiş olsa da, başka türden varlıklara nasıl indirgenebileceği ya da dönüştürebileceği ve başka modellerde nasıl kullanacağı üzerine derinlemesine yoğunlaşmış görünmektedir.

Model kavramı, klasik metafiziğin ve mantığın sınırlarını aşarak, bu sınırlar içinde kalan uzam-zamansal tecrübeye dayalı empirik bilgi nesnesinin yerine, bugünkü modern mantık sayesinde mümkün ve imkansız nesneleri içerecek metafiziklere ulaşmaya imkan veren modal mantığın "anahtar kavramı"dır. "Evrenin matematiksel bir modeli, evrenin kendisi değildir. Kısmi olsa da yaklaşık olarak anlamanın bir yoludur."(Fitting \& Mendelsohn, 1999, s. 1; Yavuz, 2020, s. 215 vd., 2021, s. 71)equality (including a treatment of Frege's morning star/evening star puzzle Merkeze aldığı konular "belirlenebilirlik ve ifade edilebilirlik" olan "[m]odel kuramı, semantikle ilgilidir; mantıksal bir dille (mantık) o dilin modelleri (yapılar) arasındaki karşılıklı etkileşimi çalışır."(Goranko \& Otto, 2007, s. 249) "Modal mantığın model kuramının kökleri, J'onsson ve Tarski ile Kripke'nin (Kripke) bağıntısal semantiğinin temellerini atan makalelerine dek gider."(Goranko \& Otto, 2007, s. 250) Bu açıklamalar ışı̆̆ında, Hârizmî’nin cebirsel denklemlerin çözümünde geometrik modelleri takip ediyor olması, 20. yüzyılda felsefe ve mantık alanında yaşanan bu gelişmelerle ilişkisel 
bir benzerlik göstermektedir. Cantor'un kümeler kuramı yoluyla sayılabilir ve sayılamaz sonsuza dair açıklamalarının, Löwenheim-Skolem teoremi sayesinde, modeli olan herhangi bir teorinin sayılabilir bir alanda da geçerli olduğunun kanıtlanmasıyla anlam kazandığına daha önce değinilmişti. Yani, örneğin, sayılamaz sonsuza ilişkin teorinin bir model içinde tanımlanması yoluyla sayılamaz sonsuz alana ait (bireyleştirilemeyen, tanımlanamayan, ne olduğuna ilişkin henüz hakkında yeterli bilgi olmayan) bir sayının da sayılabilir sonsuz alandaki bir nesne gibi varlık kazanmasının yolu açılmıştır. Bunun felsefi değerlendirmesi, ontolojik bir birey olarak tanımadığımız, hakkında bilgi sahibi olmadığımız fakat bir model dahilinde kapsanabilecek herhangi bir şeyin nesne kuramında yerini alabilmesinin imkânını ifade eder. Bu dünyadan erişilebilir mümkün bir dünyayı anlamanın ve o dünyanın mümkün nesnelerine dair yargıda bulunabilmenin yolu da onun bir modelini oluşturmak ve bu model üzerinde geçerli bağıntıları tanımlamakla mümkündür. Hârizmînnin yapmış olduğu tam da böyle bir şeydir: bilinen bir noktadan ve belirli birkaç adımdan hareketle bir model oluşturup, henüz olmayan ama olması muhtemel başka durumlarda aynı adımları tekrar ederek başka bir önermenin (matematiksel açıdan, denklemin) doğruluk değerini belirlemeye çalıșmak. Böylece, uygun adımlardan geçerek, henüz varolmamış bir nesne (ya da herhangi bir denklemin kökü olmayan bir sayı), belirlenen model dahilinde, varolan (veya mümkün) bir nesne (ya da çözüme kavuşmuş bir denklemin kökü olan bir sayı) haline gelebilir. Öte yandan, model oluşturarak cebri inşa etmenin, çok açıkça, semantik bir karşılığı vardır. Cebirsel denklemleri geometrik modelleme yoluyla çözmesinin ardındaki saik, cebir ve anlam arasındaki bağı da inşa etme çabası, diğer bir ifadeyle, cebrin anlamsal dayanağını kaybetmeme çabasındadır. Modellerinde negatif sayılara ve köklere yer vermemesinin nedeni de budur. İnşa ettiği cebrin semantiğinde negatiflerin açıklaması yoktur, zira negatifin varlıksal (uzamsal) bir karşılığı yoktur. Ancak, negatif olmayan fakat ne olduğunu bilmediğimiz büyüklüklere (gibi) inşa ettiği modeller üzerinden erişebilir ve bu yolla bildiklerine ne kadar yakın olduğunu anlamaya çalışır.(Şener Öztürk, 2021, s. 40) Yukarıdaki alıntıyı tekrarlayacak olursak "evrenin bir modeli, evreni yaklaşık olarak anlamanın bir yolu"dur. Hârizmî'nin inşa ettiği modelden anlıyoruz ki, onun evreninde negatifler yer almazken; bireyleştiremediği pozitif büyüklükler, bireyleştirebildiklerine kıyas yoluyla anlaşılarak yer bulabilir.(Yavuz, 2021, ss. 71-72) Denilebilir ki, modal semantiğin kurucusu olan Kripke, "adlar ve betimler arasındaki” bağıntının izini sürerken(Kripke, 2005, s. 37), Hârizmî de sayılar ve kareler arasındaki ilişkinin izini sürüyor ve geometrik modellerle inşa ettiği bu ilişkide, semantiği sentaksa önceleyerek, kimi türden sayıları dışarıda bırakan ve kimi türden sayıları ise bireyleștiremese bile sistemine dahil eden bir metafiziği temele alıyor.

\section{SONUÇ}

Kaleme alınışında on iki asır sonra dilimize kazandırılan Hârizmî Cebr'i, bugünkü felsefi ve matematiksel birikimle okunduğunda hayli ilginç ve önemli yorum ve çıkarımlara götürür. Yüzeysel bir bakışla, kitap son derece "olağan" yöntem ve içeriğe sahip gibi görünse de, bugün için bile gerek matematik gerekse felsefi açıdan yeni ufuklar açacak niteliktedir. Metin boyunca değinmeye çalıştığımız matematik, bilim ve felsefenin çoğu zaman karınca adımlarıyla ilerleyişi göz önünde bulundurulduğunda dönemine göre hiç de küçümsenemeyecek bir başarı örneğidir. Çalışmamız boyunca ilişkilendirdiğimiz isimlerin 19. yüzyıl ve sonrasında bu tartışmaları henüz yürütüyor olması, Hârizmî’nin yönteminin o gün için ne denli önemli olduğunun ayrıca kanıtıdır. Burada sunmaya çalıştığımız, Cebr'in metafizik ve semantik bir dayanağının bulunduğu yönündeki felsefi ve mantıksal yorumların yanı sıra, son iki yüzyılda yapılmaya başlanan tartışmalar şayet eserin verildiği 9. yüzyıl itibariyle yapılmaya başlanmış olsaydı günümüz bilim ve fikriyatının bugün ne denli ileride olabileceğine yönelik bir çıkarımda bulunmak da mümkündür. Yahut da, insanl1ğın düşünsel (ve ahlaki) evriminin, bilimsel (d)evrimlerden daha hızlı gelişmesi sağlanabilir ya da belki en azından bunlar karşısında mağlup duruma düşmesine engel olmada daha başarılı olunabilirdi.

Her matematik kitabının aynı zamanda bir felsefe kitabı olduğu varsayımıyla yola çıkarken, insanoğlunun bir yerlerde kaybettiği "anlam"ı arayışının ortak bir çabası olarak Hârizmî Cebr'ini felsefi açıdan okumaya çalıştığımızda, Hârizmînin de kendi anlamını kaybetmeme çabası içinde olduğunu gördük. Bu çabayla, metafizik bir temele dayanarak, inşa ettiği sistematik cebrin bir semantiğini veren kendi alanının ilk ve en iyi örneklerinden birini bizlere miras bırakmıştır. Dilimizdeki ilk ve tek çeviriye dayanarak yaptığımız felsefi çıkarımlar da, bu açıdan, ilk mülahazalar olup geliştirilmeye muhtaçtır.

\section{KAYNAKÇA}

Aristoteles. (1996). Metafizik (Ahmet Arslan, Çev.). Sosyal Yayınları.

Brentano, F. (2009). Psychology from An Empirical Standpoint. Routledge; Taylor \& Francis e-Library.

Brun, J. (1997). Stoa Felsefesi (M. Atıcı, Çev.). Illetişim Yayınları.

Dantzig, T. (2011). Sayı: Bilimin Dili (Barış Cezar, Çev.). Metis Yayınları.

Dürüşken, Ç. (2013). Stoa Mantığı. Felsefe Arkivi, 28.

Ekinci, İ. (2021). Harizmî'nin Kitâbu'l-Cebr ve'l-Mukâbele İsimli Eserinin Arap Dilindeki Yeri ve Önemi. İçtimaiyat.

Fazlıoğlu, í. (1997). Hârizmî, Muhammed b. Mûsâ -. İçinde TDV İlam Ansiklopedisi (C. 16, ss. 224-227).

Fitting, M., \& Mendelsohn, R. L. (1999). First-Order Modal Logic (Softcover reprint of the original 1st ed. 1998 Edition). Kluwer Academic Publishers. 
Goranko, V., \& Otto, M. (2007). Model Theory of Modal Logic. Studies in Logic and Practical Reasoning (C. 3, ss. 249-329). Elsevier.

Hârizmî, M. b. M. (2021). Cebir ve Denklem Hesabı Üzerine Özet Kitap-Çeviri-Inceleme (İsmail Ekinci, Tuğba Yavuz, Beyhan Ş. Öztürk, Çev.). DBY Yayınları.

İbn-i Sina. (2017). Metafizik I (Ömer Türker \& Ekrem Demirli, Çev.). Litera Yayıncılık.

Kripke, S. A. (2005). Adlandırma \& Zorunluluk (B. Açıl, Çev.). Litera Yayıncılık.

Launay, M. (2016). Çetele Kemiklerinden Yapay Zekaya Matematiğin Kısa Tarihi (G. Ünal, Çev.). Say Yayınları.

Martin, R. M. (1963). Intension and Decision: A Philosophical Study. Englewood Cliffs, N.J.: Prentice-Hall.

Meinong, A. (1960). On the Theory of Objects (Translation of "Über Gegenstandstheorie", 1904). R. Chisholm (Ed.), Realism and the Background of Phenomenology (ss. 76-117). Glencoe, Illinois: Free Press.

Muhammad ibn Musâ Khowarizmi. (1831). The Algebra of Mohammed ben Musa (F. Rosen, Çev.). London Printed for the Oriental Translation Fund and sold by J. Murray.

Nasution, M. (2018). The Uncertainty: A History in Mathematics. Journal of Physics: Conference Series, 1116, 022031.

Russell, B. (1904). Meinong's Theory of Complexes and Assumptions (I.). Mind, 13(50), 204-219.

Şener Öztürk, B. (2021). Harezmi ve Matematik. Cebir ve Denklem Hesabı Üzerine Özet Kitap. DBY Yayınları.

Tahiri, H. (2016). Mathematics and the Mind: An Introduction into Ibn Sinā's Theory of Knowledge. Springer International Publishing.

Tahiri, H. (2018). The Foundations of Arithmetic in Ibn Sinā. Içinde H. Tahiri (Ed.), The Unity of Science in the Arabic Tradition: Science Logic Epistemology and Their Interactions (C. 43, ss. 297-314). Springer International Publishing AG,.

Therrien, V. L. (2012). Inventing Logic: The Löwenheim-Skolem Theorem and First -and Second- Order Logic. Pensées Canadiennes, 10.

Türker-Küyel, M. (1992). Fârâbî’nin Geometri Felsefesine Ilişkin Metinler. Atatürk Kültür Dil ve Tarih Yüksek Kurumu Atatürk Kültür Merkezi Yayını, 1992.

Yavuz, T. (2020). Varolmayan Nesneler Semantiği. DBY Yayınları.

Yavuz, T. (2021). Çağdaş Felsefe ve Nesne Kuramı Tartışmaları Bağlamında Hârizmî̀nin Cebri. Cebir ve Denklem Hesabı Üzerine Özet Kitap. DBY Yayınları. 